\title{
Use of Secondary Crystallization and Fly Ash in Waterproofing Materials to Increase Concrete Resistance to Aggressive Gases and Liquids
}

\author{
Rostislav Drochytka $\mathbb{D}^{1},{ }^{1}$ Matej Ledl $\left(\mathbb{D},{ }^{1}\right.$ Jiri Bydzovsky $\left(\mathbb{D}^{1},{ }^{1}\right.$ Nikol Zizkova ${ }^{(D)}{ }^{1}$ \\ and Johannes Bester $\mathbb{D i D}^{2}$ \\ ${ }^{1}$ Institute of Technology of Building Materials and Components, Brno University of Technology, Faculty of Civil Engineering, \\ Brno 602 00, Czech Republic \\ ${ }^{2}$ Faculty of Engineering and the Built Environment, University of Johannesburg, Johannesburg 2094, South Africa
}

Correspondence should be addressed to Matej Ledl; ledl.m@fce.vutbr.cz

Received 21 January 2019; Revised 25 March 2019; Accepted 15 April 2019; Published 29 May 2019

Academic Editor: Emilio Bastidas-Arteaga

Copyright (c) 2019 Rostislav Drochytka et al. This is an open access article distributed under the Creative Commons Attribution License, which permits unrestricted use, distribution, and reproduction in any medium, provided the original work is properly cited.

\begin{abstract}
This paper describes the use of cement-based waterproofing screed and waterproofing coating, in which $10 \%$ of the original amount of cement was replaced by fly ash and $2 \%$ of the crystallization admixture was added by weight of cement, as a mean of protection of concrete against aggressive environments. The modified materials were applied to the underlying concrete and subjected to testing of physical and mechanical properties after exposure to effects of aggressive environments for up to 18 months. The results of the analysis have shown that after the application of waterproofing materials, there is a sufficient development of the crystals in the underlying concrete to enhance its durability. Thus, it is possible to use fly ash functionally and efficiently in polymer cement systems as a substitute for the cement together with the crystallization admixture.
\end{abstract}

\section{Introduction}

The concrete is probably the most commonly used construction material due to its versatility [1]. Unfortunately, durability is not an intrinsic property of concrete, and in certain instances, concrete needs protection from the aggressiveness of the environment. The aggressive environment may be due to chemical and physical attacks $[2,3]$. Concrete is a multi-component composite containing cement sealant, in which there are significantly more pores and capillaries than in dense aggregates. For this reason, it is much more susceptible to physical and chemical degradation. A basic factor which is a major contributor to the degradation processes is water. It may be in liquid form, vapour, or any dissolved substances. It may, by means of diffusion, capillarity, and ion exchange, penetrate into the concrete through a system of open and interconnected capillary pores and interfere with the cement sealant. Mehta and Monteiro [4] and Kumar and Bhattacharjee [5] found that the diameter of capillary pores ranges from $10 \mathrm{~nm}$ to hundreds of microns. Capillary flow is defined by the following:

$$
Q=\frac{\pi \cdot r^{4} \cdot p_{t} \cdot t}{8 \cdot \eta \cdot l}
$$

where $Q$ : volume flow $\left(\mathrm{m}^{3} \cdot \mathrm{s}^{-1}\right), \pi$ : Ludolph's number $(3.1415 \ldots), p_{t}$ : air pressure in the capillary $(\mathrm{Pa}), t$ : time $(\mathrm{s}), \eta$ : dynamic viscosity $(\mathrm{Pa} \cdot \mathrm{s}), r$ : radius of the capillary $(\mathrm{m})$, and $l$ : capillary length $(\mathrm{m})$.

From equation (1), it is evident that the radius of the capillary in the fourth power is the critical flow factor, and it is therefore appropriate to reduce the capillary diameter to slow down the rate of degradation. The affection of cement sealant by aggressive gases generated by industrial processes, combustion engines, living organisms, etc., is conditioned by humidity along with the most common aggressive gases such as $\mathrm{CO}_{2}, \mathrm{SO}_{2}, \mathrm{NO}_{2}, \mathrm{HCl}, \mathrm{H}_{2} \mathrm{~S}, \mathrm{HF}$, $\mathrm{NH}_{3}$, and $\mathrm{Cl}_{2}$. 
Diluting acidic gaseous exhalants in water creates diluted solutions of inorganic acids, which react with components of cement sealant, especially $\mathrm{Ca}(\mathrm{OH})_{2}$ [6]. The products of cement paste corrosion occupy a larger volume, thus breaking the cohesion of hardened cement paste leading to decrease in $\mathrm{pH}$ and cracking. These cracks consequently allow for an accelerated corrosion of steel reinforcement due to a quicker decrease of $\mathrm{pH}[7,8]$.

The main factors that have the greatest impact on the assessment of aggressive gaseous environments include the following:

(i) Gas concentration in the air

(ii) Relative air humidity

(iii) Temperature

(iv) Activity of more aggressive agents at the same time

Aggressive waters contain dissolved acid gases and various salts in varying concentrations. Emmons and Emmons [9] stated that depending on the nature of the corrosion products, there are three types of degradation:

Type I: degradation related to the action of water media with low salt content and predominantly neutral reaction

Type II: degradation under the influence of very aggressive media, such as acids, alkali, some salts, such as sodium or magnesium chloride

Type III: degradation due to the penetration of liquid media into the pores, which form an insoluble crystalline compound of larger volume with the pore fluid or cement sealant

Broomfield [10] mentions that one of the options for protection against corrosion media is a concrete finish that can reduce or prevent water and aggressive substances from entering its structure. Such a finish is usually used in order to protect concrete from the harmful effects of these aggressive substances. One such commonly used method is called secondary protection. For the design of secondary protection itself, the degree of aggressiveness of the environment, the type of the substrate, and the correct choice of the material for the protection must be considered. One of the subgroups of waterproofing and surface treatments are polymer cement waterproofing coatings and screeds. They represent a proven, affordable, and environmentally acceptable alternative to traditional asphalt- or polymer-based waterproofing. Flexible polymer cementitious sealants exist as two-component systems with a liquid polymeric component, mostly based on styrene-acrylate dispersion, cement binder and suitable dry filler. Alternatively, these systems are formulated on the basis of polymeric redispersible powders that allow the formation of single-component systems which are only mixed with water prior to processing [11].

Screeding and smoothing compounds, often based on ethylene-vinyl acetate, are used to level and smooth out conventional concrete beddings (monoliths and prefabricates), cement screed, or reprofilable mortars for the rehabilitation of reinforced concrete. These cement-based repair mortars present a very suitable and cost-effective solution for concrete protection as they have very similar properties as concrete, thus ensuring their mutual compatibility; moreover, such materials are partially permeable for water vapour, which allows for drying concrete out. Impermeable polymer coatings entrap the moisture in the porous cementitious substrate causing additional damage to concrete in freezing and thawing cycles. The aim is achieving a sufficiently smooth and level surface with a waterproofing function serving as a final treatment or as a suitable basis under the coating system. Current technologies allow for the use of levelling and smoothing screeds that can be applied in layers from less than $1 \mathrm{~mm}$ to $5 \mathrm{~mm}$. At the same time, it is possible to produce a material with waterproofing function, even with very low thickness of the applied layer, by means of suitable formulations and using sealing materials.

The cementitious and polymeric components of these materials increase their cost, and for that reason, there are attempts to find methods of reducing the cementitious content. One of these attempts is the partial replacement of cement with waste or secondary raw materials, such as powder fly ash or slag. The inclusion of such secondary raw materials has the added benefit of reducing the environmental impact associated with the issues of depositing waste materials and $\mathrm{CO}_{2}$ production during clinker burning. Using the fly ash as a partial replacement for cement also contributes to the increase in durability of cement composites as the fly ash is capable of pozzolanic reaction with calcium hydroxide, which produces additional calciumsilicate hydrates (C-S-H) and calcium-aluminium-silicate hydrates (C-A-S-H). They additionally cause refinement and reduction of permeability of pore structure of cement matrix as the pozzolanic reaction is slower than hydration of cement as presented in the studies of Moffatt et al. [12] and Feng et al. [13].

Another effective means of protecting and improving the durability of cement composites are surface coatings [14]. Pan et al. [15] described many advantages and disadvantages of various types of concrete surface treatments. The development of new waterproofing materials also leads to the use of special crystallization admixtures to enhance the protective function. Mostly, they are powdered substances based on finely ground cement, treated fine silica sand, and an active chemical. Conventional coatings and screeds fulfil only the surface protection function, while crystallization admixtures penetrate the pore system into the concrete structure, where it is sealed. The principle action is a catalytic chemical reaction, conditioned by sufficient relative humidity. This leads to an additional crystallization process of the still unhydrated clinker minerals in the pore system of concrete, resulting in filling practically all the capillary active pores of the concrete with needle-like crystals. The introduced active chemical, therefore, is not a source of crystals but merely a catalyst that allows for the growth of crystals within the pores of concrete from the untreated clinker minerals present in the cement sealant. During the hydration process, $\mathrm{Ca}(\mathrm{OH})_{2}$ is temporarily produced, followed by the catalytic crystallization process and the growth of the resulting crystals directly into the concrete pore 
structure. This is probably the accumulated process accompanied by the formation of $3 \mathrm{CaO} \cdot 2 \mathrm{SiO}_{2} \cdot 3 \mathrm{H}_{2} \mathrm{O}$ together with the formation of $3 \mathrm{CaO} \cdot \mathrm{Al}_{2} \mathrm{O}_{3} \cdot \mathrm{Ca}(\mathrm{OH})_{2} \cdot 12 \mathrm{H}_{2} \mathrm{O}$. In this chemical reaction, branched needle-like crystals are formed. The active substances penetrate into the pores, with moisture, to a distance of up to ten centimetres from their source and catalyze the reactions in which crystals form in the pore system of the cement sealant $[16,17]$. According to X-ray fluorescence spectroscopy (XRF), the needle-like crystals (Figure 1) probably contain calcium or silicon [18].

The speed and depth of crystal growth through the cracks and pore system of the concrete depend on many factors, such as the extent of the concrete's treatment, the presence of sufficient volume of pore water, type of cement, concrete proportioning, pore structure, and temperature of the concrete [19-24]. The general process of action has been described by Roig-Flores et al. [25], where the crystallization agent, $\mathrm{M}_{x} \mathrm{R}_{x}$, reacts with the tricalcium silicate and the water to form clots blocking the pores. This is represented by the following equation:

$$
\begin{aligned}
3 \mathrm{CaO} \cdot \mathrm{SiO}_{2}+\mathrm{M}_{x} \mathrm{R}_{x}+\mathrm{H}_{2} \mathrm{O} \longrightarrow & \mathrm{Ca}_{x} \mathrm{Si}_{x} \mathrm{O}_{x} \mathrm{R} \cdot\left(\mathrm{H}_{2} \mathrm{O}\right)_{x} \\
& +\mathrm{M}_{x} \mathrm{CaR}_{x} \cdot\left(\mathrm{H}_{2} \mathrm{O}\right)_{x}
\end{aligned}
$$

Research on secondary crystallization in cement composites has previously been dealing with the sealing of pore structures and sealing cracks. The benefits of utilisation of crystalline admixtures are well demonstrated in previously published studies [25-30]: however, improving the properties of concrete remains an important task even today [19]. Improving the durability of cementitious composites helps extend their longevity, thereby reducing repair costs associated with moisture damage of concrete structures [31]. This study pays attention to the use of the crystallization admixture in the cement-polymer waterproofing materials applied to the surface of concrete, such as coating and screed, capable of breathability, crack healing ability, good compatibility with concrete, and chemical resistance. In order to reduce the overall costs for crystalline admixtures and polymer compounds, fly ash is considered to be an environmentally friendly partial replacement for cement with a positive impact on durability due to pozzolanic reaction.

\section{Materials and Methods}

2.1. Materials. In order to decrease the permeability of the concrete surface against water, gaseous, and liquid aggressive environments, two insulating materials were developed and applied to the surface of the concrete. The insulating materials were applied as a coating (CT) and a screed (SC). Both materials utilized a crystallization admixture (Xypex Admix) and fly ashas a secondary raw material.

The thin coating layer copying the concrete surface is applied to the concrete with the use of a brush or roller, whereas the screed that compensates for the unevenness of the concrete is applied using a steel trowel. The concrete

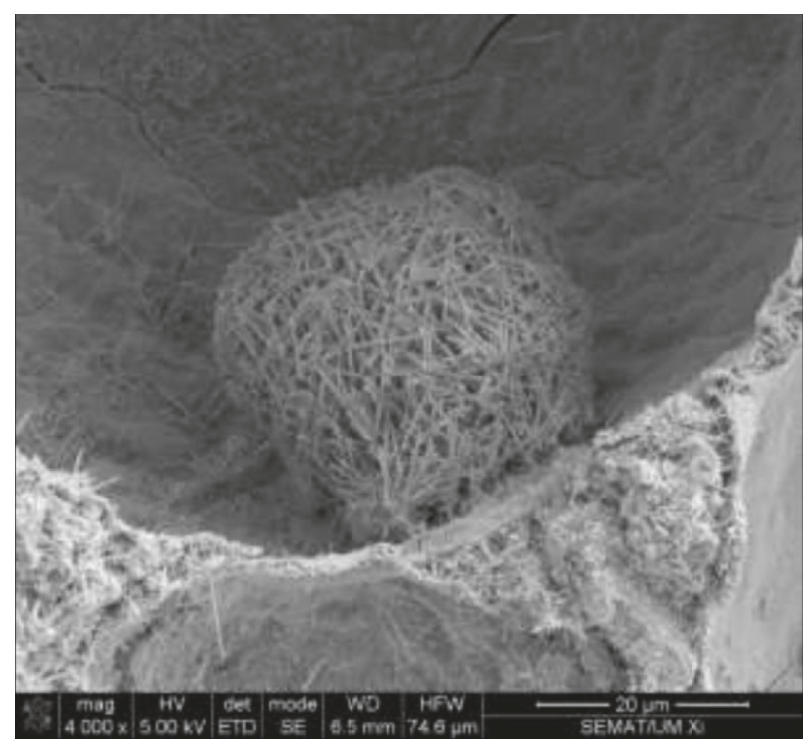

FIGURE 1: SEM image of the crystalline form inside the concrete pore at a depth of $15 \mathrm{~mm}$ below the surface 12 days after application of the Xypex Concentrate crystallization coating [18].

specimens ( $150 \mathrm{~mm}$ cubes) of C $45 / 55$ reference concrete were used. The reference concrete was tested according to EN 1542 [32] and EN 12390-3 [33] and yielded a compressive strength of $52 \mathrm{MPa}$ and tensile strength of $3.2 \mathrm{MPa}$. The composition of the reference concrete (REF) is given in Table 1. Specimens were matured for 28 days at an ambient temperature of $21 \pm 3^{\circ} \mathrm{C}$ and a relative humidity of $60 \pm 10 \%$, followed by epoxy coating on the sides and immersed in water for 48 hours. Subsequently, the surface without epoxy was wiped with a rug and an insulating screed or a coating was applied to the damp surface of the concrete specimens (Figure 2) using a brush (coating) and a steel trowel (screed). After application, the specimens were covered with a plastic foil. After 72 hours, the plastic foil was removed and the specimens were cured for another 28 days in an environment with a relative humidity of $60 \pm 10 \%$ and a temperature of $21 \pm 3^{\circ} \mathrm{C}$, which lead to the start of the test or to the exposure to the aggressive environments. This storage enabled the active substances to penetrate into the pore structure of the underlying concrete and thus allowed for the formation of secondary crystallization products, reducing the pore diameter in concrete.

As a waterproofing material with a crystallization admixture, a polymer cement coating (CT) with $10 \%$ cement replacement by fly ash and addition of $2 \%$ of crystallization admixture by weight of cement was developed. The second tested material was a screed (SC) with $10 \%$ cement replacement by fly ash and addition of $2 \%$ of crystallization admixture by weight of cement. The composition of both materials is shown in Tables 2 and 3. The mix design of both waterproofing materials was based on the general knowledge of the behaviour of individual components and industrially used products. The average thickness of the coating is designed to be $1.5 \mathrm{~mm}-2 \mathrm{~mm}$ with respect to the maximum grain size of sand. The screed was applied in designed thickness of $3 \mathrm{~mm}-5 \mathrm{~mm}$. 
TABle 1: Composition of reference concrete (REF).

\begin{tabular}{lc}
\hline Material & Dosage $(\mathrm{kg})$ \\
\hline Cement EN 197-1 CEM II/A-S 42.5 R & 340 \\
Sand 0/4 & 1280 \\
Gravel 4/8 mined & 200 \\
Gravel 4/8 crushed & 221 \\
Silica fume (5\% aqueous dispersion) & 120 \\
Water & 150 \\
\hline
\end{tabular}

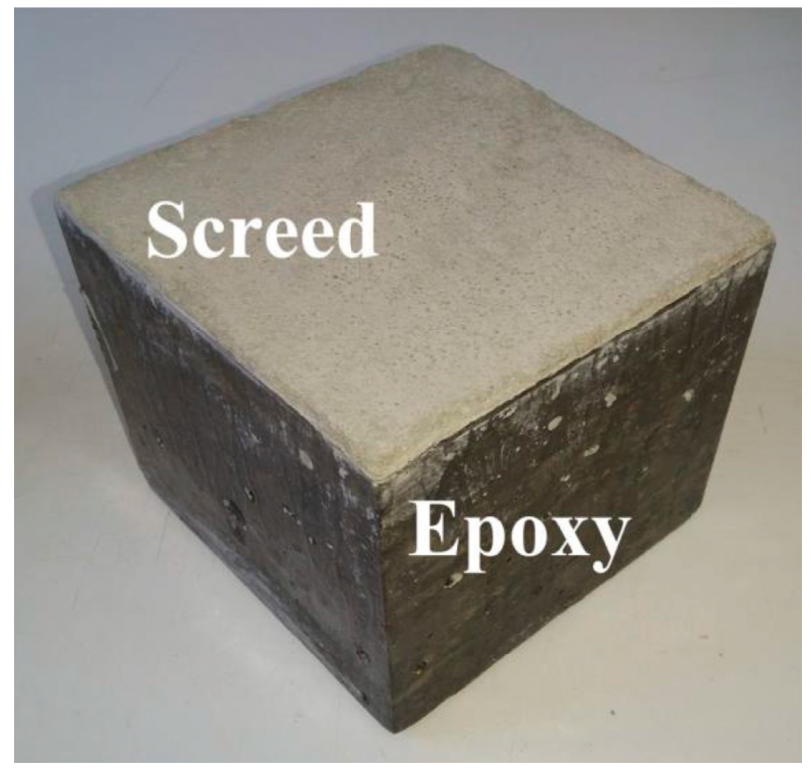

Figure 2: Concrete specimen with the screed applied on the face and epoxy coating on remaining sides of concrete (REF).

TABLE 2: Composition of polymer cement coating (CT).

\begin{tabular}{lc}
\hline Material & Dosage $(\mathrm{kg})$ \\
\hline Cement EN 197-1 CEM II/A-S 42.5 R & 270 \\
Silica sand & 700 \\
Silica fume (5\% aqueous dispersion) & 8 \\
Silica filler & 20 \\
Fly ash $\left(10 \%^{*}\right)$ & 30 \\
Xypex Admix $\left(2 \%^{*}\right)$ & 6 \\
Water & 300 \\
Carboxymethyl cellulose & 10 \\
Styrene-acrylate dispersion & 700 \\
Defoaming agent on synthetic copolymer base & 5 \\
\hline
\end{tabular}

${ }^{*}$ Percentual substitute for cement was based on the initial dose $300 \mathrm{~kg} / \mathrm{m}^{3}$ of cement.

The physical and chemical compositions of the raw materials used are given in Table 4 and in Figure 3. Phase composition of crystalline admixture in Figure 4.

2.2. Testing Methods. 3 batches of concrete specimens were prepared (REF, REF treated with CT, and REF treated with SC) for 7 selected environments (Table 5). For 6, 12, and 18 months, they were exposed to the environment and after each interval a complex testing programme was carried out, allowing to assess the state of the secondary crystal
TABle 3: Composition of polymer cement screed (SC); * percentual substitute for cement was based on the initial dose $270 \mathrm{~kg} / \mathrm{m}^{3}$ of cement.

\begin{tabular}{lc}
\hline Material & Dosage $(\mathrm{kg})$ \\
\hline Cement EN 197-1 CEM II/A-S 42.5 R & 248 \\
Silica sand & 450 \\
Ground limestone & 250 \\
Silica filler & 120 \\
Polymeric dispersion powder on vinyl acetate and & 3.5 \\
ethylene base & 0.5 \\
Polypropylene fibres & 220 \\
Water & 1 \\
Superplasticizer on polycarboxylates base & 1 \\
Carboxymethyl cellulose & 27.5 \\
Fly ash (10\%*) & 5.4 \\
Xypex Admix $\left(2 \%^{*}\right)$ &
\end{tabular}

development, their possible degradation, their impact on the durability of the concrete, and its resistance to the selected environment, compared to untreated reference concrete. The testing programme included the following:

(1) The water absorption was determined on 3 specimens ( $150 \mathrm{~mm}$ concrete cubes) of each batch according to EN 14617-1 [34].

(2) Depth of penetration of water under pressure was determined on 3 specimens ( $150 \mathrm{~mm}$ concrete cubes) at different ages according to EN 12390-8 with water pressure of $500 \pm 50 \mathrm{kPa}$ for $72 \pm 2 \mathrm{~h}$ [35].

(3) Scanning electron microscopy (SEM) was carried out after the exposure of the specimens to an aggressive environment for 18 months. The presence of crystals and their evolution with respect to the age and effects of degradation were observed on test specimens, cut out of the remains of $150 \mathrm{~mm}$ concrete cubes after determination of depth of penetration of water under pressure using a circular saw with a diamond blade. The fragments of concrete were taken from the depth of $15 \mathrm{~mm}$ below the interface of treatment and the sound concrete, dried out, and sized down to the size approximately $5 \mathrm{~mm} \times 5 \mathrm{~mm} \times 5 \mathrm{~mm}$. A thin layer of gold 300-400 $\AA$ was applied to the samples using the Quorum Q150r. Gold-plated, now conductive, samples were inserted into the body of the FEI Nova 200 , and the shots were taken at a suitable resolution (magnification of $4,000 \mathrm{x}$ to $25,000 \mathrm{x}$ ).

(4) For the determination of $\mathrm{pH}$ values of concrete with treated and untreated surfaces, respectively, the samples were extracted from 3 specimens $(150 \mathrm{~mm}$ concrete cubes) at a depth of approximately $15 \mathrm{~mm}$. First, the samples were taken before placing the specimens in an aggressive environment. After 18 months of exposure, the $\mathrm{pH}$ test was performed again. The samples were extracted from the cubes using $40 \mathrm{~mm}$ diamond core drill. Consequently, the holes were filed up with epoxy resin in order to prevent aggressive environment from penetrating the specimens. This allowed reuse of the specimens for the $\mathrm{pH}$ test after 18 months. For the $\mathrm{pH}$ test, 
TABLE 4: Physical and chemical characteristics of materials.

\begin{tabular}{|c|c|c|c|c|c|c|}
\hline \multirow{2}{*}{ Component } & \multicolumn{6}{|c|}{ Content (\%) } \\
\hline & CEM & Fly ash & Silica filler & Silica sand & Silica fume & Crystalline admixture \\
\hline $\mathrm{SiO}_{2}$ & 18.28 & 56.82 & 99.1 & 99 & 91.97 & 11.5 \\
\hline $\mathrm{Al}_{2} \mathrm{O}_{3}$ & 4.96 & 28.93 & 0.27 & 0.3 & 0.1 & 2.34 \\
\hline $\mathrm{Fe}_{2} \mathrm{O}_{3}$ & 3.67 & 6.18 & 0.098 & 0.03 & 0.67 & 1.74 \\
\hline $\mathrm{TiO}_{2}$ & - & 2.02 & 0.38 & 0.05 & 0.02 & 0.129 \\
\hline $\mathrm{CaO}$ & 64.9 & 1.79 & - & - & 0.19 & 45.7 \\
\hline $\mathrm{MgO}$ & 2.00 & 1.31 & - & - & 1.24 & 0.734 \\
\hline $\mathrm{MnO}$ & - & 0.03 & - & - & - & 0.102 \\
\hline $\mathrm{K}_{2} \mathrm{O}$ & 1.02 & 1.79 & - & - & 3.32 & 0.387 \\
\hline $\mathrm{Na}_{2} \mathrm{O}$ & 0.20 & 0.32 & - & - & 0.5 & 6.61 \\
\hline $\mathrm{SO}_{3}$ & 3.71 & 0.36 & - & - & 0.67 & 2.05 \\
\hline$S$ & - & 0.2 & - & - & - & - \\
\hline Specific surface $\left(\mathrm{m}^{2} / \mathrm{kg}\right)$ & 378 & 250 & 17.5 & - & 150000 & 386 \\
\hline
\end{tabular}

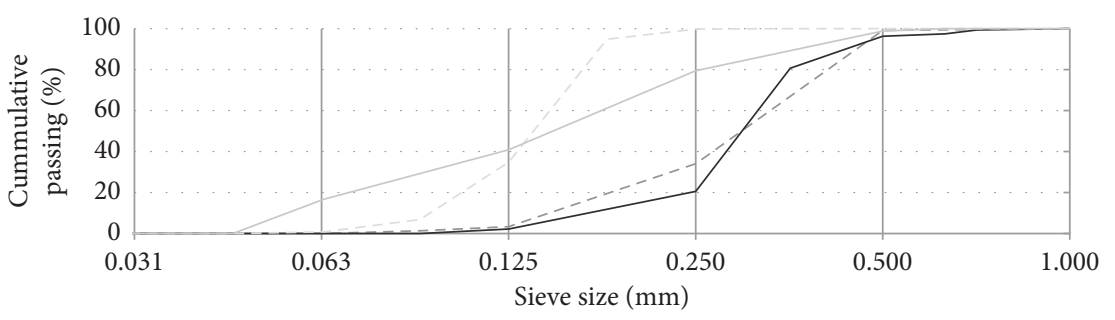
Ground limestone
Silica filler
Fly ash

- Silica sand

FIgURE 3: Particle size distribution of raw materials.

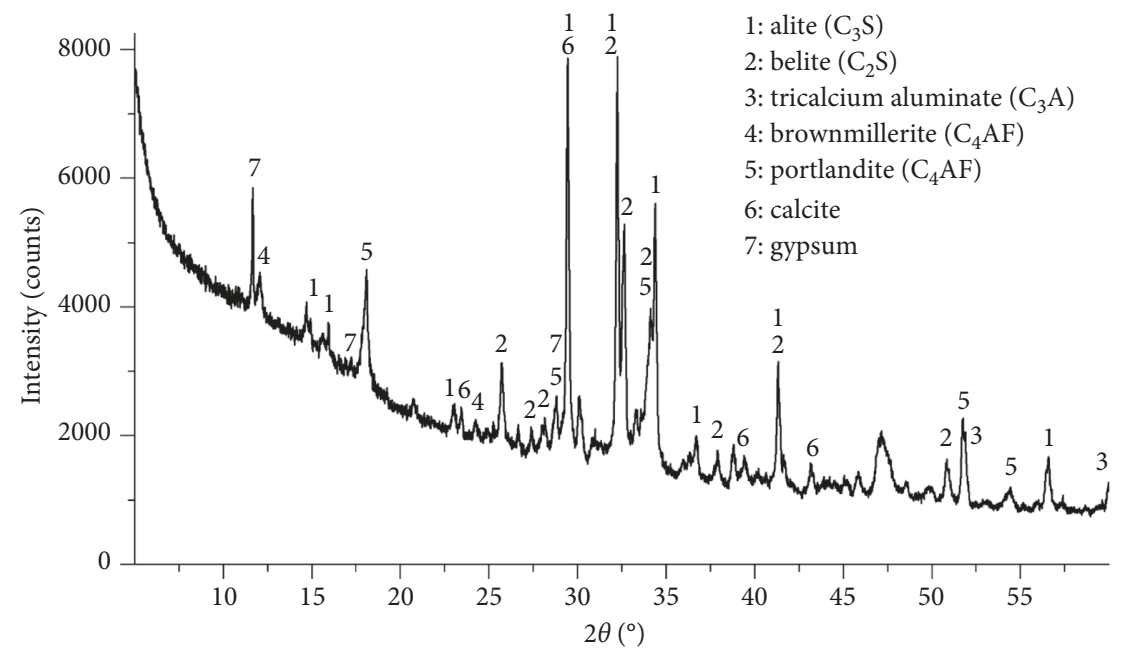

FIgURE 4: X-ray diffraction analysis of crystalline admixture.

TABle 5: Description of aggressive environments.

\begin{tabular}{|c|c|c|c|c|}
\hline Environment & & Concentration & Relative humidity & Temperature \\
\hline Gaseous & $\begin{array}{l}\mathrm{CO}_{2} \\
\mathrm{CO}_{2} \\
\mathrm{SO}_{2} \\
\end{array}$ & $\begin{array}{c}\text { Low: } 1-2 \% \\
\text { High: } 5-10 \% \\
\text { High: } 5-10 \%\end{array}$ & $60 \pm 10 \%$ & $21 \pm 2^{\circ} \mathrm{C}$ \\
\hline Liquid & $\begin{array}{c}\mathrm{SO}_{4}{ }^{2-} \\
\mathrm{SO}_{4}{ }^{2-} \\
\mathrm{Cl}^{-} \\
\end{array}$ & $\begin{array}{c}\mathrm{Na}_{2} \mathrm{SO}_{4} \cdot 10 \mathrm{~g} / \mathrm{l} \\
\mathrm{Na}_{2} \mathrm{SO}_{4} \cdot 34.6 \mathrm{~g} / \mathrm{l} \\
\mathrm{NaCl} \cdot 100 \mathrm{~g} / \mathrm{l}\end{array}$ & & $21 \pm 2^{\circ} \mathrm{C}$ \\
\hline
\end{tabular}

Real outdoor environment*

${ }^{*}$ The real environment shows the effects of climatic influence on samples stored outdoors where during the exposure, the temperatures alternate ranging from

$-15.9^{\circ} \mathrm{C}$ to $+34.8^{\circ} \mathrm{C}$. Samples were also exposed to irregular precipitation, direct sunlight, air pollution, and biological agents. 
$10 \mathrm{~mm}$ thick section of the core sample was cut out at a distance of $10 \mathrm{~mm}$ from the interface of treatment and sound concrete or from the untreated surface of REF concrete, respectively. Oven-dried $\left(60^{\circ} \mathrm{C}\right.$ for $24 \mathrm{~h})$ sections were then milled and sieved through the mesh $(0.063 \mathrm{~mm})$. After that, $10 \mathrm{~g}$ of material was separated and dispersed in $100 \mathrm{~g}$ of distilled water. After mixing in electromagnetic mixer for 30 minutes, the solution was filtered and the $\mathrm{pH}$ value determined in solution using $\mathrm{pH}$ meter.

2.3. Exposure Environment. The resistance of the proposed waterproofing materials was verified by placing the specimens in the aggressive media defined in Table 5 for 6-18 months.

The gaseous environments were created in the Köhler Automobiltechnik GmbH salt spray chambers HK 400-800/ M/WTG (Figure 5) which can accommodate 32 specimens in 4 layers separated vertically with polymer grids. Specimens were placed in chamber with the treated side against the door in order to prevent the aggressive condensates from remaining on the treated side of the specimen.

\section{Results and Discussion}

3.1. Water Absorption. Based on the evaluation of the results of the water absorption test of concrete samples treated with the coating and the screed, it is suggested that these materials significantly reduce the water absorption. Changes in the water absorption after the exposures in liquid aggressive environments can be clearly seen in Figures 6 and 7 in the case of exposure to gaseous media. In all environments, untreated concrete (REF) showed a higher total water absorption than concrete with a waterproofing coating or screed. Especially after 18 months in the liquid environment, the greatest differences in absorbency between the treated concrete and the reference concrete are observed. This indicated the effectiveness of the use of the screed and especially the coating, which has in all cases the lowest absorption, even after exposure in a highly concentrated sulphate environment. In an environment with $\mathrm{NaCl}$, however, the coating appears to be less resistant than in the environment with a high concentration of sulphates.

Gaseous environments with a high $\mathrm{SO}_{2}$ concentration and, in particular, $\mathrm{CO}_{2}$ have significantly influenced the water absorption of the samples. This suggests that a coating may be a more effective protective material against gaseous aggressive environments than a screed.

The real environment, compared to a highly concentrated long-term liquid and gas environment (18 months), shows much less aggressiveness and less damage to treated and untreated concrete.

Absorbance values generally fluctuated at low values due to the possibility of penetration of the liquid through only one nonepoxy surface; therefore, it was also necessary to verify this test with the depth of penetration of water under pressure.
3.2. Depth of Penetration of Water under Pressure. The test for the determination of penetration of water under pressure according to EN 12390-8, due to the effect of increased water pressure on the tested sample, provides a sharper and more conclusive possibility of comparing the ability of treated concrete to resist water and aggressive substances, as opposed to untreated concrete. The screed and coating increased the resistance of concrete structures against penetration of water under pressure as opposed to untreated concrete (REF).

Figures 8 and 9 compare the absorption values of both treated and untreated concrete samples in the corrosive environment, after six, twelve, and eighteen months in the aggressive environment.

Untreated concrete always exhibited a higher depth of penetration of water under pressure than concrete treated with a coating and with the screed, which was also confirmed by the water absorption tests. The samples were also assessed according to the design limit values for the composition and properties of the concrete according to EN 206 + A1. All concrete samples with an applied treatment, after 18 months of storage, had a depth of penetration of water under pressure lower than $50 \mathrm{~mm}$, a value corresponding to the resistance to XA1, XS4, XF1, XF2, and $\mathrm{XD} 2$ environments. Samples treated with a coating specifically for XD3 environment, corrosion caused by chlorides other than the sea, and chemically aggressive XA3 environments had withstood the test with the exception of environments with high concentrations of $\mathrm{CO}_{2}$ and $\mathrm{SO}_{2}$ ions because the limit values of the depth of penetration are $20 \mathrm{~mm}$ [36]. Based on these results, it can be stated that, in terms of water permeability, the tested crystallization materials are suitable for structures exposed to water under pressure. Regarding the resistance of the tested materials against the penetration of aggressive gases, leakage results indicate that the resistance is comparable to the influence of the liquid medium.

3.3. SEM Analysis of Crystal Growth. SEM was performed in order to detect secondary crystallization products and to monitor the impact of aggressive media on the concrete microstructure. Images for the two most aggressive liquid and two gaseous environments were selected.

In the liquid $\mathrm{NaCl}$ and $\mathrm{Na}_{2} \mathrm{SO}_{4}$ medium shown in Figures 10 and 11, a more pronounced developed elongated flattened crystals of about $20 \mu \mathrm{m}$ can be observed filling the pores. These crystals are incompletely shaped, but their amount and size indicate that the initial absorption and the liquid environment have provided sufficient moisture to fill the pores with secondary crystallization. There are no clearly identifiable crystals in the images that would indicate significant signs of carbonation, sulphation, or degradation due to aggressive environments. On the contrary, a sufficiently dense cement matrix is evident. Larger pores can also be expected to be filled.

Figures 12 and 13 from the $\mathrm{CO}_{2}$ and $\mathrm{SO}_{2}$ gaseous media again show rod-like crystals penetrating the pores. Crystals filling the pores differ in shape and size, their amount and 


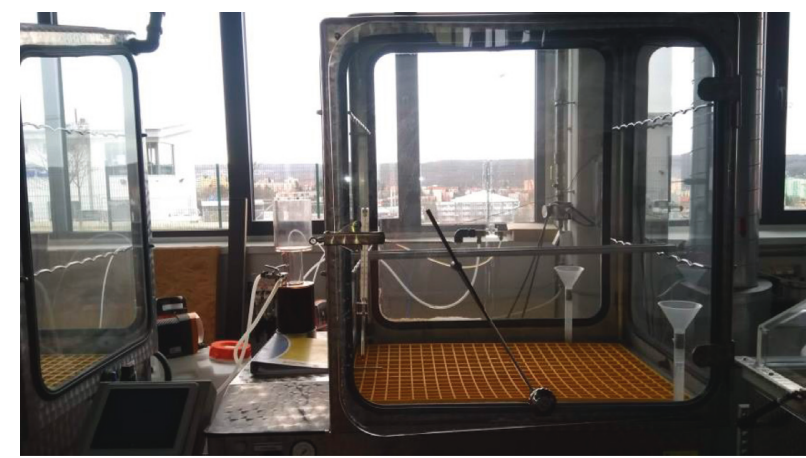

FIgURE 5: Salt spray chamber for the gaseous environment.

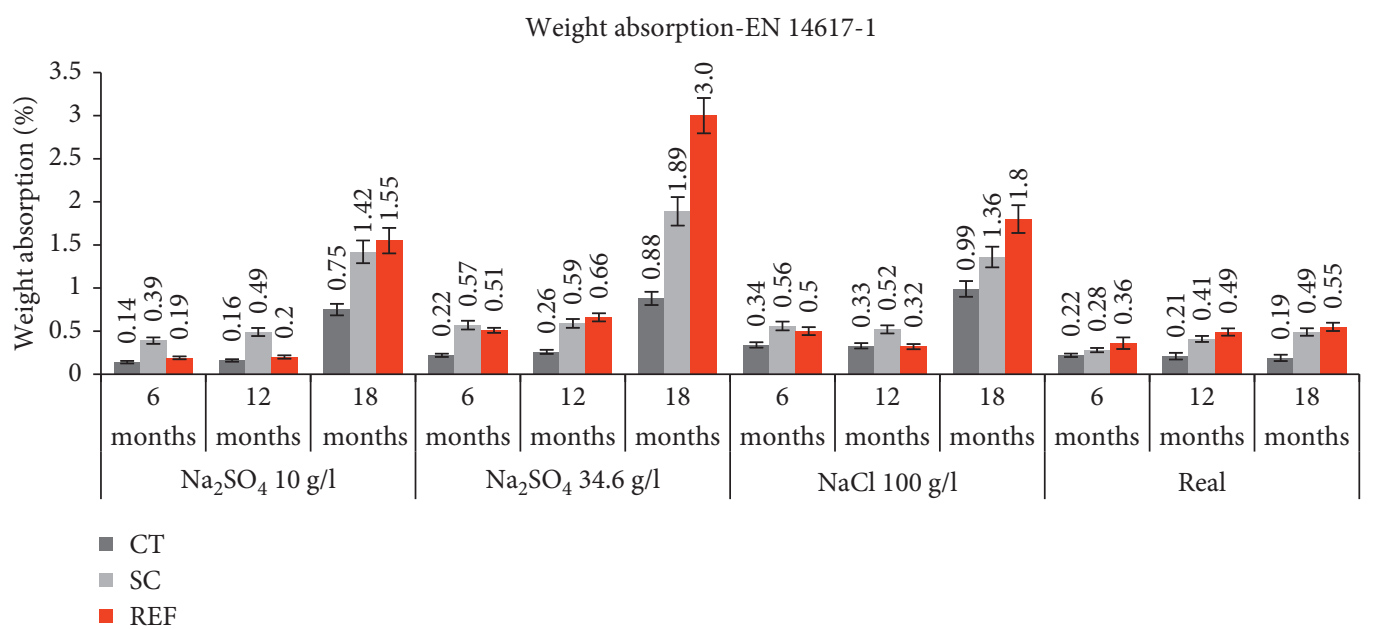

Figure 6: Comparison of the absorption of concrete exposed to liquid aggressive media and the real environment. The error bars represent the range of measurements for 3 samples.

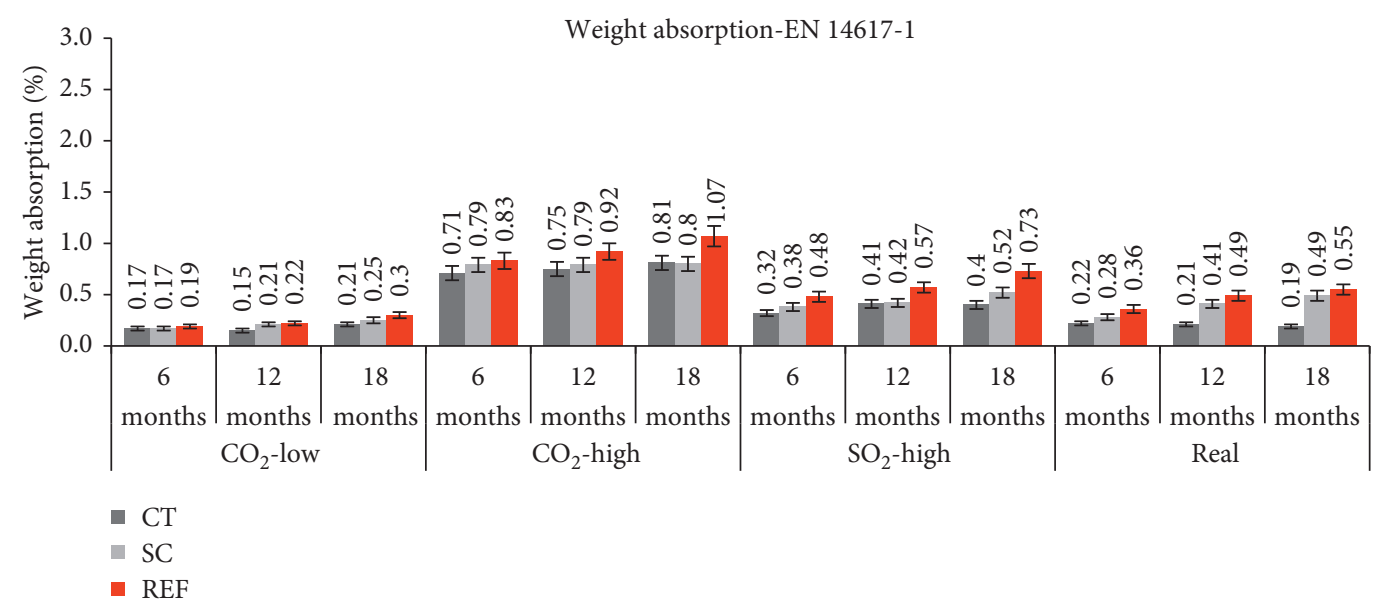

Figure 7: Comparison of the absorption of concrete exposed to gaseous aggressive environments and the real environment. The error bars represent the range of measurements for 3 samples.

size are substantially smaller, and their clusters are of a smaller and finer structure than the samples stored in the liquid environment. The humidity inside the pores probably was not sufficient enough for crystal growth to a larger extent. It can be concluded that most of the pores filled had a diameter of less than $20 \mu \mathrm{m}$.
3.4. Changes in the pH of Concrete. Figure 14 shows $\mathrm{pH}$ values before storage and after 18 months in aggressive environments. The graph is sorted downwards according to the change of $\mathrm{pH}$ during the exposure to the aggressive environment.

The most obvious decrease in $\mathrm{pH}$ can be clearly seen in the untreated concrete (REF). Mostly in $\mathrm{NaCl}$ and real 


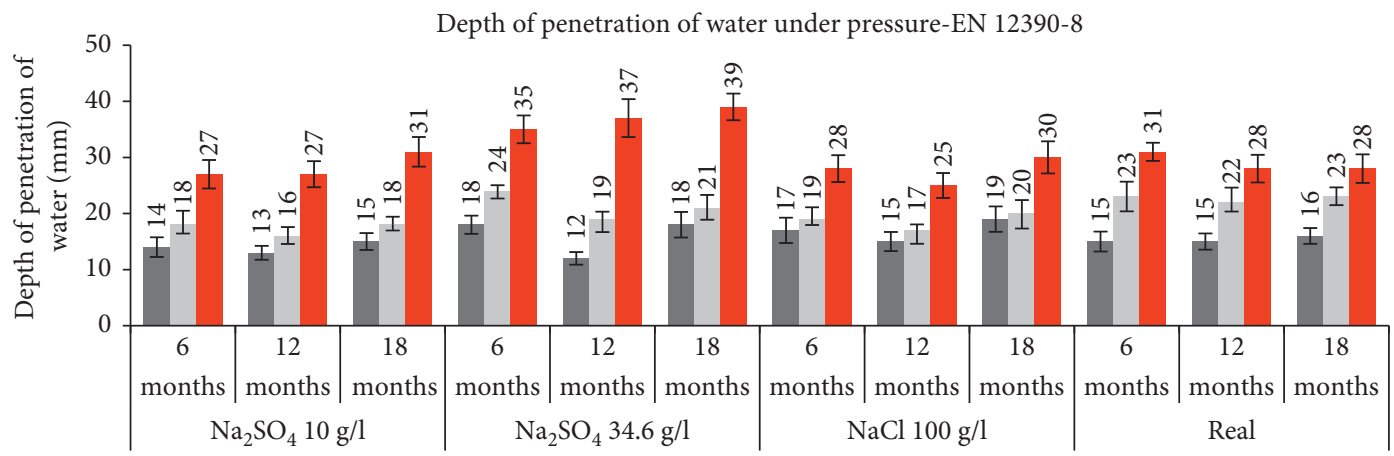
- $\mathrm{CT}$
$\square \mathrm{SC}$
- REF

Figure 8: Comparison of depth of penetration of water under pressure in concrete exposed to a liquid aggressive environment and a real environment. The error bars represent the range of measurements for 3 samples.

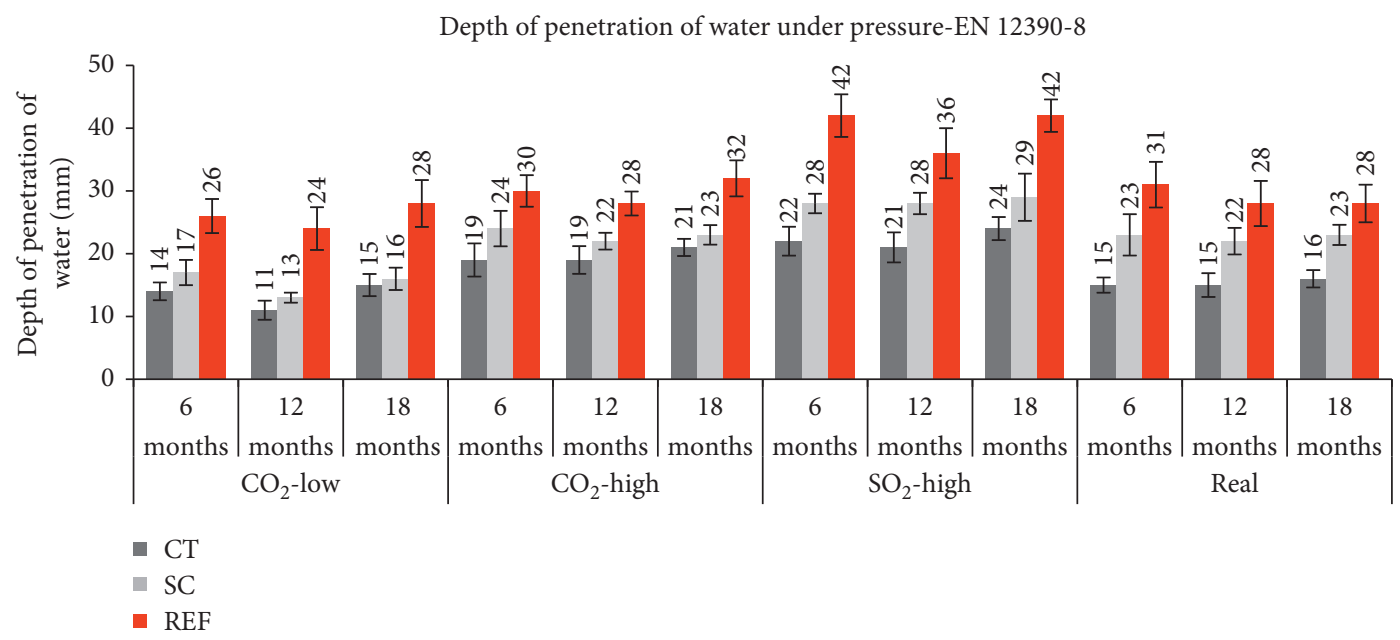

FIGURE 9: Comparison of depth of penetration of water under pressure in concrete exposed to a gaseous aggressive environment and a real environment. The error bars represent the range of measurements for 3 samples.

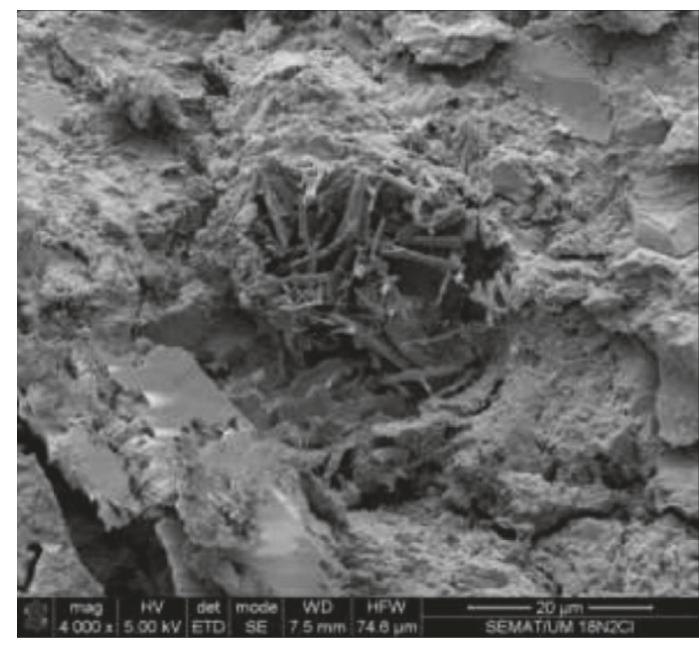

(a)

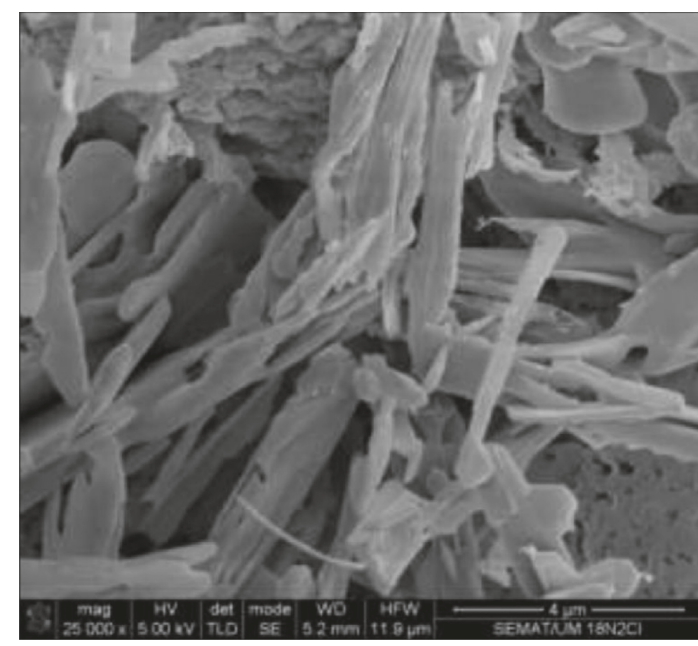

(b)

Figure 10: (a) The SEM shot of the concrete treated with coat after 18 months in liquid $\mathrm{NaCl}$ environment; (b) a detail of the formed Friedel's salt crystals $\left(3 \mathrm{CaO} \cdot \mathrm{Al}_{2} \mathrm{O}_{3} \cdot \mathrm{CaCl}_{2} \cdot 10 \mathrm{H}_{2} \mathrm{O}\right)$. 


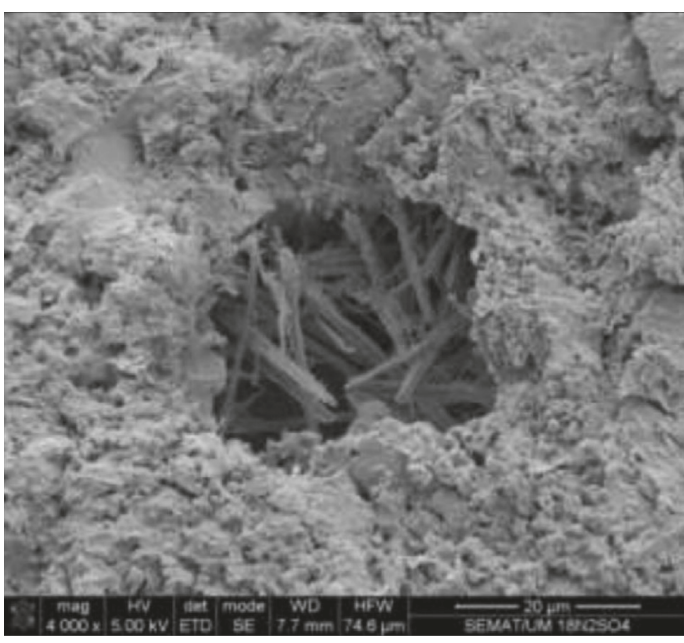

(a)

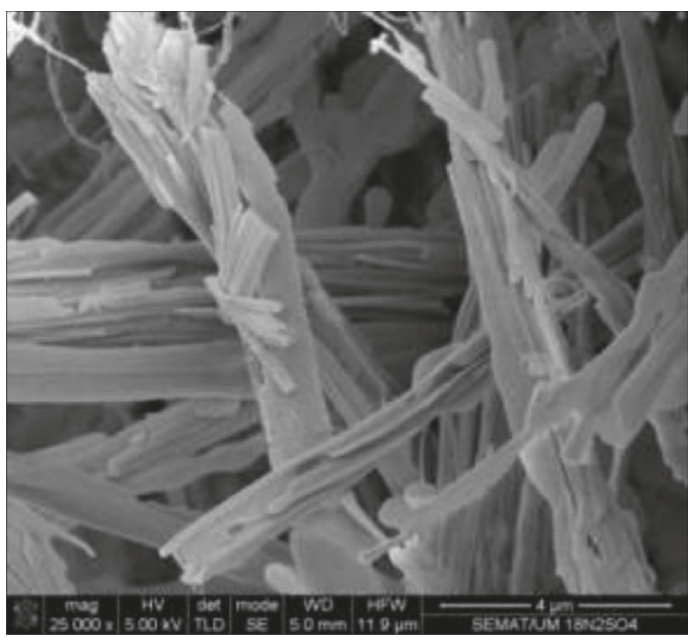

(b)

Figure 11: (a) The SEM shot of the concrete treated with coat after 18 months in liquid $\mathrm{Na}_{2} \mathrm{SO}_{4}$; (b) a detail of the formed ettringite crystals.

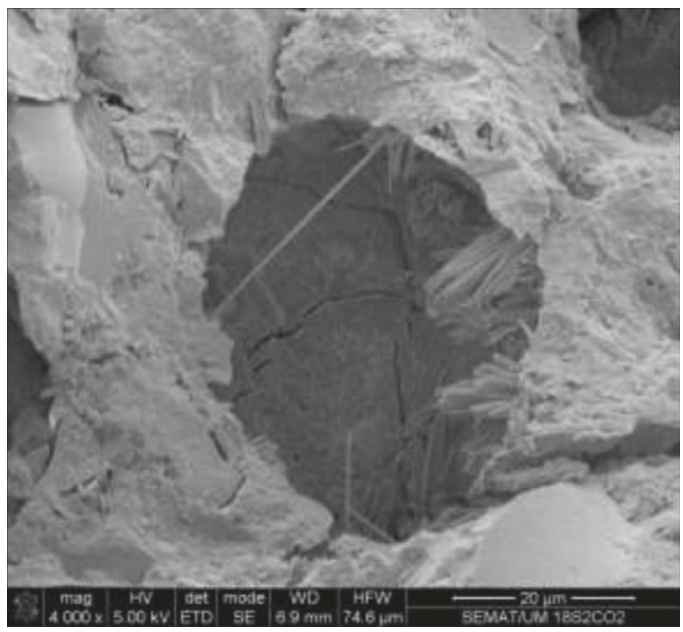

(a)

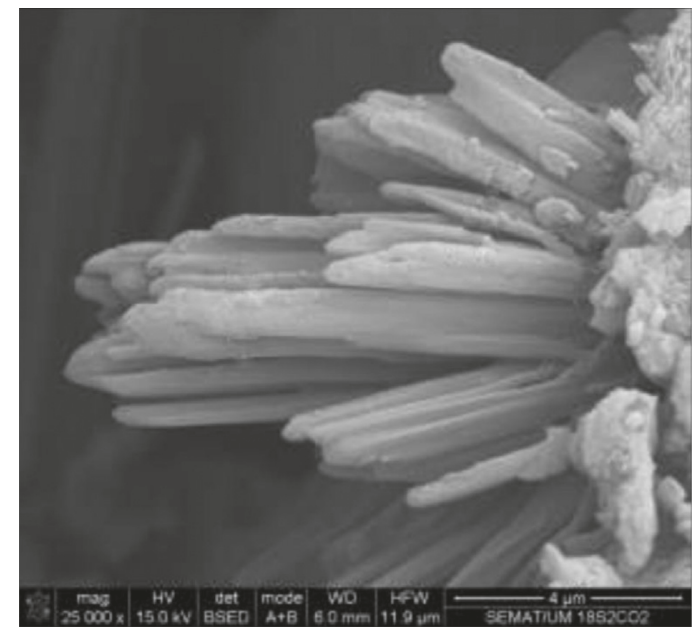

(b)

FIgURE 12: (a) The SEM shot of concrete treated with screed after 18 months in gaseous $\mathrm{CO}_{2}$ environment; (b) a detail of created pseudomorphoses of aragonite crystals.

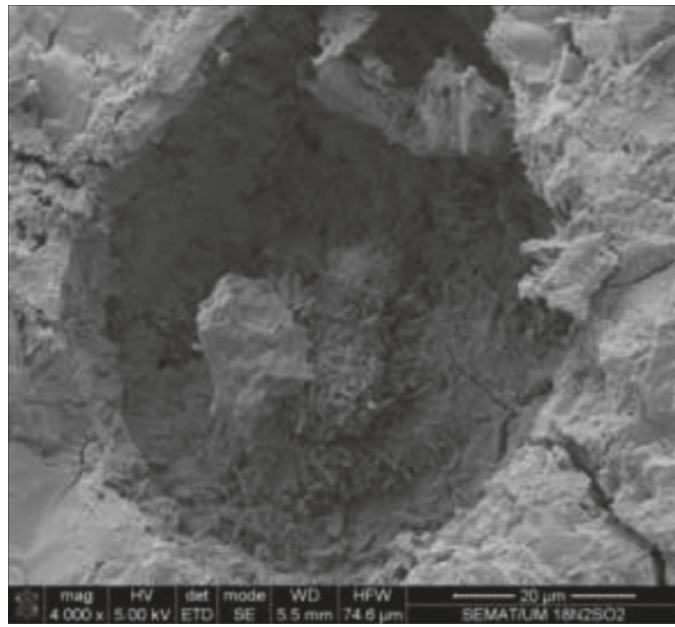

(a)

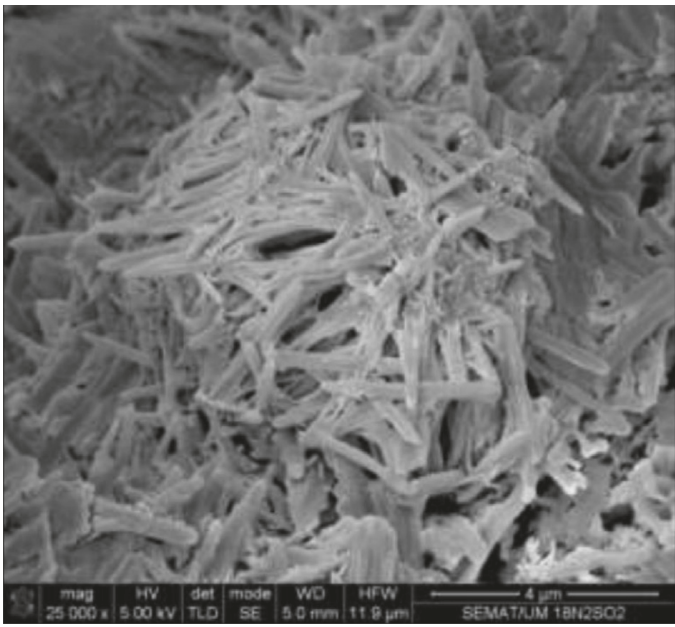

(b)

Figure 13: (a) A shot of concrete treated with coat after 18 months in gaseous $\mathrm{SO}_{2}$ environment; (b) a detail of created pseudomorphosis of gypsum crystals. 


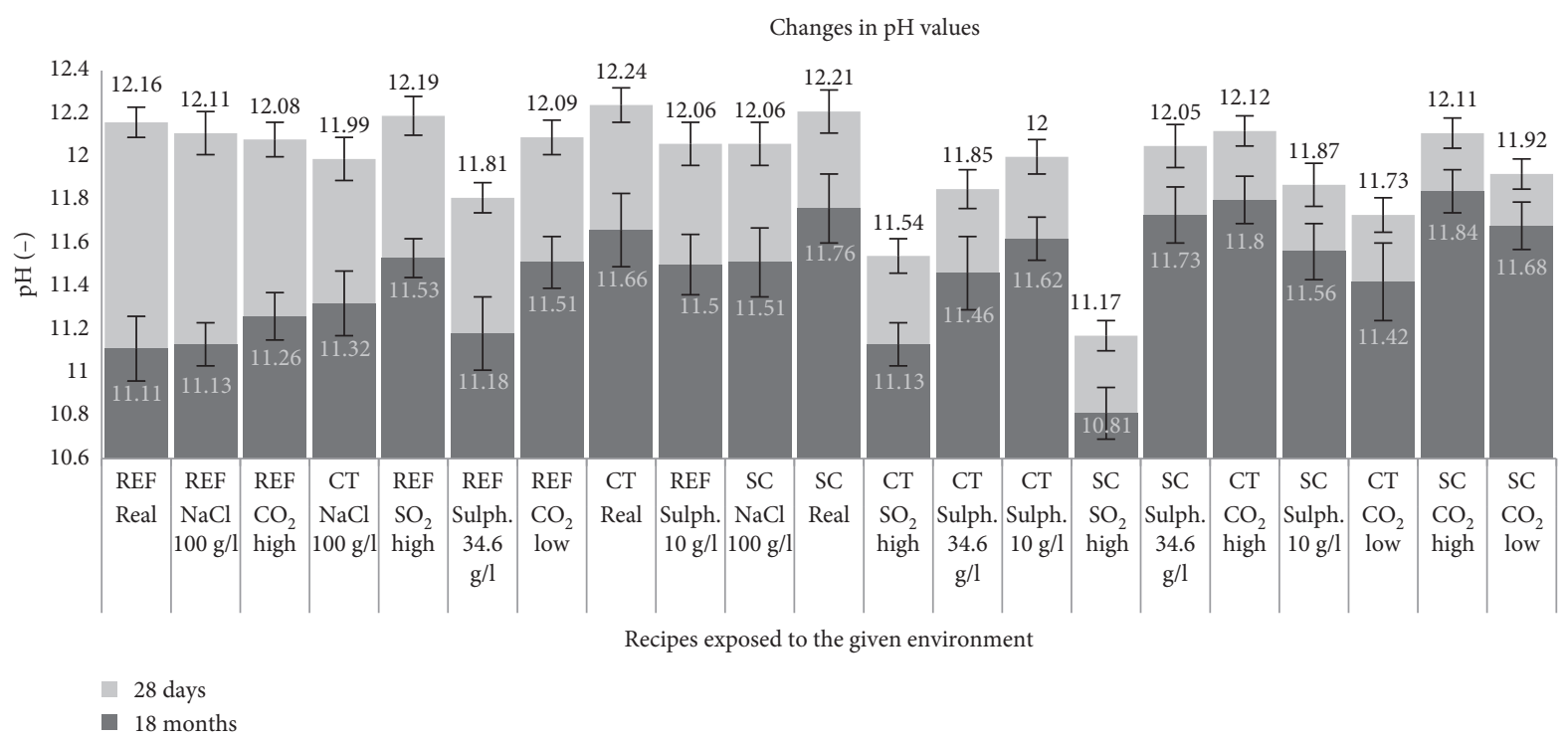

Figure 14: Changes in $\mathrm{pH}$ values in leachate for concrete samples before storage in aggressive environment and after 18 months in aggressive environment. The error bars represent the range of measurements for 3 samples.

environments, the $\mathrm{pH}$ values of concrete with coating showed a significant decrease. This may be due to coat breakage during application, manipulation, and exposure and also due to the formation of Friedel's salt within the pores. In general, it can be observed that the tested coatings and screeds successfully helped to slow down the rate of $\mathrm{pH}$ reduction during the exposure of concrete to an aggressive environment.

It turned out that at a depth of $15 \mathrm{~mm}$ from the surface of concrete, even after 18 months, there was no significant $\mathrm{pH}$ decrease (below 9.6) in concrete and, as such, it would not cease to perform the steel reinforcement protection function.

\section{Conclusions}

(i) It has been demonstrated that the polymer cement waterproofing materials with crystallization admixture can be successfully modified with fly ash additive in order to reduce the content of cement in the formulations by $10 \%$.

(ii) The functionality of the crystallization admixture in polymer cement systems has been proved.

(iii) The modification of the waterproofing materials and therefore the reduction of $\mathrm{Ca}(\mathrm{OH})_{2}$ content necessary for crystallization and crystal formation in the proposed formulations did not cause a drop in the $\mathrm{pH}$ value to the critical limit of the monitored concrete samples where the reinforcement would no longer be protected.

(iv) It was confirmed that the type of environment had a significant influence on the properties of the tested concrete sample treated with the proposed waterproofing materials.

(v) Throughout the whole 18-month exposure, the coating and screed modified by fly ash and crystallization admixture Xypex Admix have shown increased resistance to aggressive environments with a much higher concentration than is common.

(vi) The functionality of sealing technology of concrete pores with crystalline neoplasm after 18 months in an aggressive environment was verified at a depth of $15 \mathrm{~mm}$ below the interface of sound concrete, especially if liquid water was available. In concrete, where no liquid water was present in aggressive environment, the formation of crystals occurred to a much lesser extent.

(vii) The needle-shaped crystals with the maximum length of $15 \mu \mathrm{m}$ of single crystals mostly filled out pores with sizes of about $20 \mu \mathrm{m}$.

(viii) Designed formulations of crystallization coatings and screeds with the admixture of fly ash have shown very good complex properties in increasing the protection of concrete even with long-term exposure to aggressive agents $\left(\mathrm{CO}_{2}, \mathrm{SO}_{2}, \mathrm{SO}_{4}{ }^{2-}\right.$, $\mathrm{Cl}^{-}$, and real outdoor conditions).

\section{Data Availability}

The data used to support the findings of this study are included within the article.

\section{Conflicts of Interest}

The authors declare that there are no conflicts of interest regarding the publication of this paper.

\section{Acknowledgments}

This paper was created with the financial support of the Grant Agency of the Czech Republic (No. 16-25472S) "Dynamics of degradation of cement composites modified by secondary crystallization" and the project (No. LO1408) 
"AdMaS UP-Advanced Materials, Structures and Technologies," supported by the Ministry for Education, Youth and Sports of the Czech Republic under "National Sustainability Programme I."

\section{References}

[1] B. Addis, Fundamentals of Concrete, Cement and Concrete Institute, Midrand, South Africa, 1st edition, 2008.

[2] J. Basson and Y. Ballim, "Durability of concrete," in Fulton's Concrete Technology, p. 153, 7th edition, Cement and Concrete Institute, Midrand, South Africa, 1994.

[3] K. Sisomphon, O. Copuroglu, and E. A. B. Koenders, "Selfhealing of surface cracks in mortars with expansive additive and crystalline additive," Cement and Concrete Composites, vol. 34, no. 4, pp. 566-574, 2012.

[4] P. K. Mehta and P. J. M. Monteiro, Concrete Microstructure Properties, McGraw-Hill Professional Publishing, New York, USA, 2005.

[5] R. Kumar and B. Bhattacharjee, "Porosity, pore size distribution and in situ strength of concrete," Cement and Concrete Research, vol. 33, no. 1, pp. 155-164, 2003.

[6] ASM Handbook, Materials Selection and Design-Design for Oxidation Resistance, Vol. 20, ASM International, Geauga County, OH, USA, 1997.

[7] M. Eglington, Resistance of Concrete to Destructive Agencies, Lea's Chemistry of Cement and Concrete, Butterworth-Heinemann, Oxford, UK, Fourth edition, 1998.

[8] S. Xu, N. Xie, X. Cheng et al., "Environmental resistance of cement concrete modified with low dosage nano particles," Construction and Building Materials, vol. 164, pp. 535-553, 2018.

[9] P. H. Emmons and B. W. Emmons, Concrete Repair and Maintenance Illustrated: Problem Analysis, Repair Strategy; Techniques (RSMeans), Rockland, MA, USA, 1992.

[10] J. P. Broomfield, Corrosion of Steel in Concrete: Understanding Investigation and Repair, Taylor \& Francis, London, UK, 2003.

[11] M. Angel and H. J. Denu, Waterproof Membranes for Concrete Surface Protection, Farbe \& Lack, Hanover, Germany, 1997.

[12] E. G. Moffatt, M. D. A. Thomas, and A. Fahim, "Performance of high-volume fly ash concrete in marine environment," Cement and Concrete Research, vol. 102, pp. 127-135, 2017.

[13] J. Feng, J. Sun, and P. Yan, "The influence of ground fly ash on cement hydration and mechanical property of mortar," Advances in Civil Engineering, vol. 2018, Article ID 4023178, 7 pages, 2018.

[14] M. J. Al-Kheetan, M. M. Rahman, and D. A. Chamberlain, "Influence of early water exposure on modified cementitious coating," Construction and Building Materials, vol. 141, pp. 64-71, 2017.

[15] X. Pan, Z. Shi, C. Shi, T.-C. Ling, and L. Ning, "A review on concrete surface treatment part I: types and mechanisms," Construction and Building Materials, vol. 132, pp. 578-590, 2017.

[16] S. Bohus and R. Drochytka, "Cement based material with crystal-growth ability under long term aggressive medium impact," Applied Mechanics and Materials, vol. 166-169, pp. 1773-1778, 2012.

[17] S. Bohus, R. Drochytka, and L. Taranza, "Fly-ash usage in new cement-based material for concrete waterproofing," Advanced Materials Research, vol. 535-537, pp. 1902-1906, 2012.

[18] R. Drochytka and Š. Bohuš, "Microstructural analysis of crystalline technology by NANOSEM-FEI NOVA 200," in
Proceedings of the 18th International Conference on Composite Materials, pp. 92-96, Jeju Island, Korea, August 2011.

[19] T.-L. Weng and A. Cheng, "Influence of curing environment on concrete with crystalline admixture," Monatshefte für Chemie-Chemical Monthly, vol. 145, no. 1, pp. 195-200, 2014.

[20] K. Sisomphon, O. Copuroglu, and E. A. B. Koenders, "Effect of exposure conditions on self healing behavior of strain hardening cementitious composites incorporating various cementitious materials," Construction and Building Materials, vol. 42, pp. 217-224, 2013.

[21] V. Rahhal, V. Bonavetti, A. Delgado, C. Pedrajas, and R. Talero, "Scheme of the Portland cement hydration with crystalline mineral admixtures and other aspects," Silicates Industriels, vol. 74, no. 11-12, pp. 347-352, 2009.

[22] W. Guiming, Y. Jianying, and Y. J. Wuhan, "Self-healing action of permeable crystalline coating on pores and cracks in cement-based materials," Journal of Wuhan University of Technology-Mater. Sci. Ed.vol. 20, no. 1, pp. 88-92, 2005.

[23] C. Edvardsen, "Water penetrability and autogenous healing of separation cracks in concrete," Betonwerk und FertigteilTechnik, vol. 62, no. 11, pp. 77-85, 1996.

[24] N. Žižková, L. Nevřivová, and M. Lédl, "Durability of cement based mortars containing crystalline additives," Defect and Diffusion Forum, vol. 382, pp. 246-253, 2018.

[25] M. Roig-Flores, F. Pirritano, P. Serna, and L. Ferrara, "Effect of crystalline admixtures on the self-healing capability of early-age concrete studied by means of permeability and crack closing tests," Construction and Building Materials, vol. 114, pp. 447-457, 2016.

[26] V. G. Cappellesso, N. D. S. Petry, D. C. C. D. Molin, and A. B. Masuero, "Use of crystalline waterproofing to reduce capillary porosity in concrete," Journal of Building Pathology and Rehabilitation, vol. 1, no. 1, p. 9, 2016.

[27] K. L. Wang, T. Z. Hu, and S. J. Xu, "Influence of permeated crystalline waterproof materials on impermeability of concrete," Advanced Materials Research, vol. 446-449, pp. 954960, 2012.

[28] L. Ferrara, V. Krelani, and M. Carsana, "A "fracture testing" based approach to assess crack healing of concrete with and without crystalline admixtures," Construction and Building Materials, vol. 68, pp. 535-551, 2014.

[29] R. P. Borg, E. Cuenca, E. M. Gastaldo Brac, and L. Ferrara, "Crack sealing capacity in chloride-rich environments of mortars containing different cement substitutes and crystalline admixtures," Journal of Sustainable Cement-Based Materials, vol. 7, no. 3, pp. 141-159, 2018.

[30] L. Ferrara, T. Van Mullem, M. C. Alonso et al., "Experimental characterization of the self-healing capacity of cement based materials and its effects on the material performance: a state of the art report by COST Action SARCOS WG2," Construction and Building Materials, vol. 167, pp. 115-142, 2018.

[31] N. Z. Muhammad, A. Keyvanfar, M. Z. A. Majid, A. Shafaghat, and J. Mirza, "Waterproof performance of concrete: a critical review on implemented approaches," Construction and Building Materials, vol. 101, pp. 80-90, 2015.

[32] EN 1542, Products and Systems for the Protection and Repair of Concrete Structures. Test Methods-Measurement of Bond Strength by Pull-off, European Committee for Standardization, Europe, 1999.

[33] EN 12390-3, Testing Hardened Concrete. Part 3-Compressive Strength of Test Specimens, European Committee for Standardization, Europe, 2002. 
[34] EN 14617-1, Agglomerated Stone: Test Methods. Part 1-Determination of Apparent Density and Water Absorption, European Committee for Standardization, Europe, 2005.

[35] EN 12390-8, Testing Hardened Concrete. Part 8-Depth of Penetration of Water Under Pressure, European Committee for Standardization, Europe, 2017.

[36] EN 206+A1, Concrete-Specification, Performance, Production and Conformity, European Committee for Standardization, Europe, 2013. 


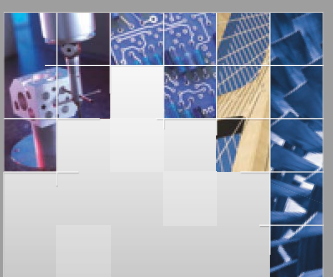

\section{Enfincering}
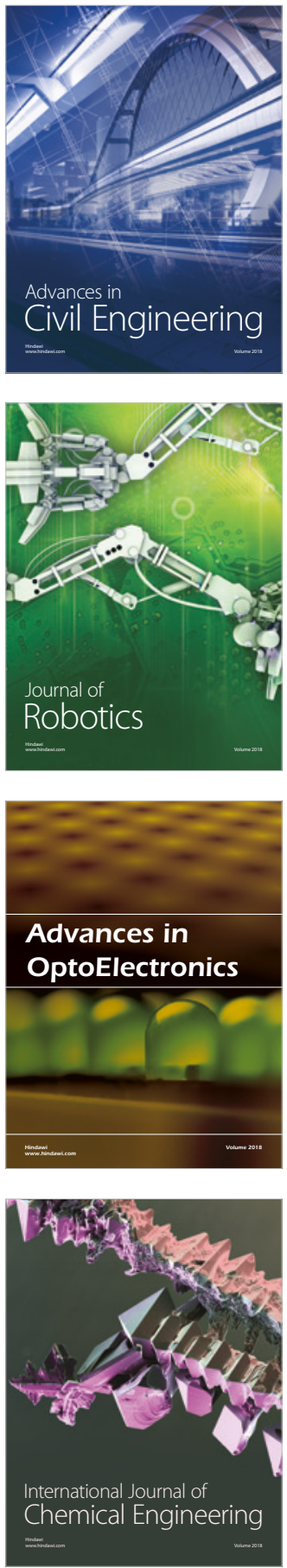

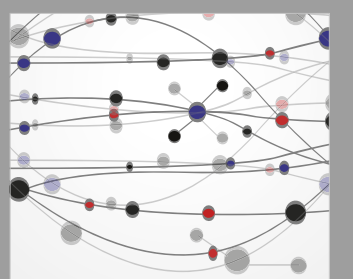

\section{Rotating \\ Machinery}

The Scientific World Journal

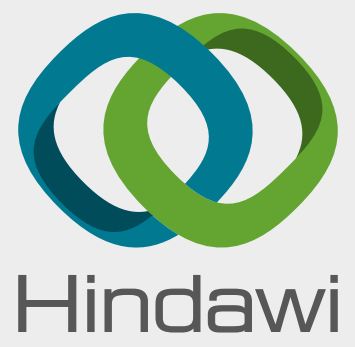

Submit your manuscripts at

www.hindawi.com
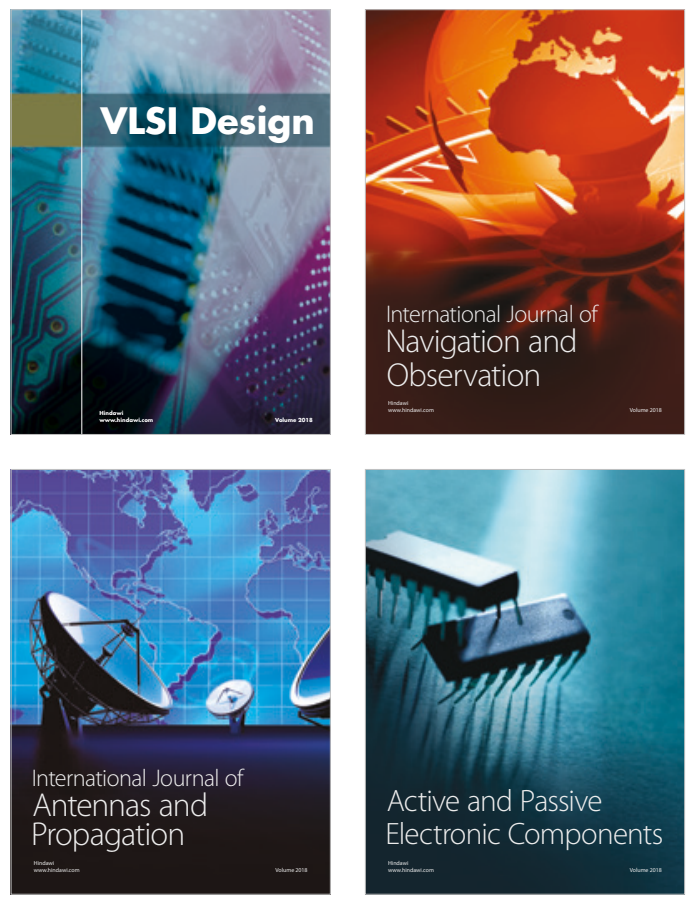
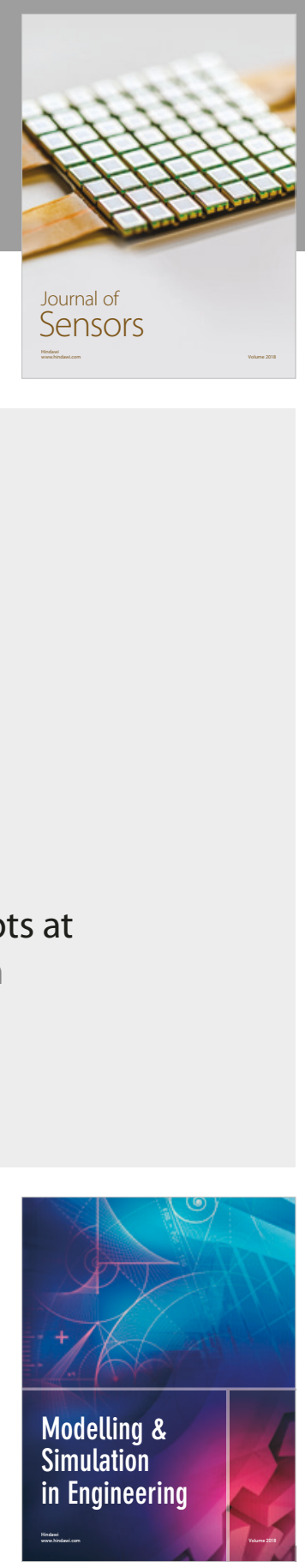

\section{Advances \\ Multimedia}
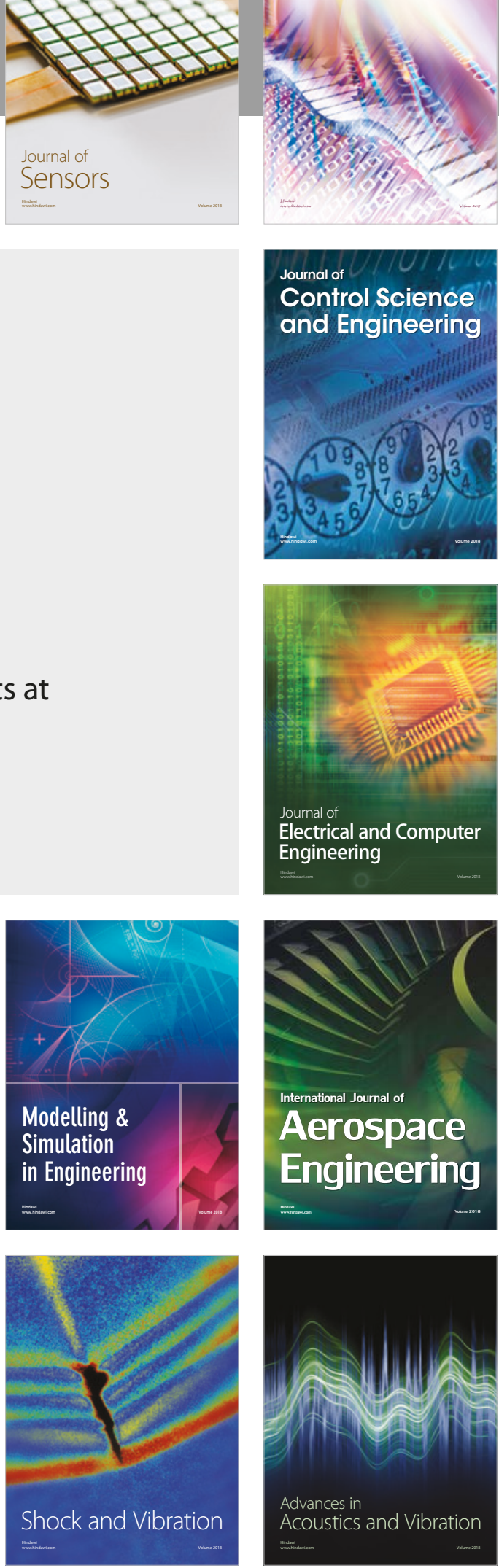